\title{
ANALISIS PREFERENSI DAN PROSPEKTIF PARTISIPATIF DALAM PERENCANAAN PENATAAN DAN PENYESUAIAN ULANG LAHAN (LAND READJUSTMENT) KAWASAN KAMPUNG BRAGA BANDUNG
}

Analysis of Preference and Participatory Prospective on Arraggement and Land Readjustment Planning in Kampung Braga Bandung

\section{Ake Wihadanto ${ }^{1}$, Baba Barus², Noer Azam Achsani3and Deddy S. Bratakusumah ${ }^{4}$}

\begin{abstract}
Abstrak: Penelitian ini bertujuan untuk memetakan preferensi dan potensi partisipatif masyarakat untuk kepentingan rencana penataan kawasan tersebut. Penelitian ini menggunakan analisis kualitatif deskriptif melalui wawancara dan FGD, selanjutnya, dengan menggunakan analisis prospektif partisipatif, preferensi masyarakat tersebut direpresentasikan melalui beberapa variabel yaitu Transparansi, Posisi tawar masyarakat, Kejelasan penguasaan dan pemilikan lahan, Komunikasi, Nilai lahan, Kelembagaan, Nilai ekonomi lokasi, dan Potensi konflik. Berdasarkan variabel-variabel tersebut, dikembangkan gambaran kondisi ke depan yang disusun dalam skenarioskenario: (1) Status-quo; (2) negatif; (3) positif; dan (4) progresif. Arah antisipasi untuk kedua skenario yang kurang/tidak mendukung (Skenario 1 dan 2) adalah menutup atau menghambat jalan bagi terciptanya kondisi dalam kedua skenario tersebut. Sementara itu, untuk kedua skenario yang mendukung (skenario 3 dan 4), arah antisipasinya adalah mendorong atau mempercepat pencapaian kondisi menurut kedua skenario, menjaga keberlanjutan dari kondisi tersebut, dan menutup atau menghambat jalan bagi bergeraknya kondisi ke arah sebaliknya. Kedua arah antisipasi tersebut diupayakan melalui aspek-aspek transparansi, komunikasi, dan kelembagaan.
\end{abstract}

\section{Keyword: Analisis preferensi, Analisis prospektif partisipatif, Penyesuaian ulang lahan}

Abstract: This research is purported to understand and map people's preferences on rearrangement plan of the area. General description of people's preferences is resulted by using qualitative descriptive analysis on data gained from interview and FGD. Furthermore, by employing Participatory Prospective Analysis (PPA) the people's preferences has represented through the following key variables, those are transparency, people's bargaining position, tenurial (ownership) system, communication, land value, institution/organization, location's economic value, and level of conflict potential. Based on those variables, the future's scenarios are constructed as follows: (1) Status quo; (2) Negative; (3) Positive; and (4) Progressive. The way to anticipate the first two scenarios are to close or impede any room or possibilities of the scenarios' emergence. Meanwhile, for the last two scenarios, the anticipation way is

\footnotetext{
${ }^{1}$ Program Studi Ilmu Perencanaan Wilayah dan Perdesaan, Sekolah Pasca Sarjana Institut Pertanian Bogor.

2 Program Studi Ilmu Tanah dan Sumber Daya Lahan, Institut Pertanian Bogor

${ }^{3}$ Program Studi Ilmu Ekonomi, Fakultas Ekonomi dan Manajemen, Institut Pertanian Bogor

${ }^{4}$ Kementrian Perencanaan Pembangunan Nasional/Badan Perencanaan Pembangunan Nasional (Bappenas) Republik Indonesia
}

Korespondensi: ake.wihadanto@gmail.com 
to promote or enhance the scenarios' emergence, maintaining sustainability of the scenarios, as well as avoiding any ways that can reverse the scenarios' direction. Both ways of anticipation should be carried out through transparency, communication, and institution.

Keywords: Preference analysis, Participatory Proscpective Analysis, Land readjustment.

\section{PENDAHULUAN}

Kawasan Kampung Braga Bandung merupakan suatu perkampungan penduduk yang membentuk kelompok perumahan seperti 'kantung' (enclave) di tepian Sungai Cikapundung yang rentan terhadap banjir, longsor dan kebakaran. Kawasan permukiman ini menyatu dalam kawasan yang mempunyai beragam fungsi kegiatan seperti: pertokoan, perdagangan, hotel, mal, perkantoran, jasa dan usaha kecil lainnya. Letaknya yang sangat strategis ini mendorong perkembangan permukiman Kampung Braga tumbuh tidak terencana dan semakin padat (Hapsariniaty et al. 2012). Kondisi Kampung Braga yang semakin padat ini menyebabkan lingkungan permukiman tersebut menjadi kumuh dan tidak layak huni. Di kawasan tersebut kondisi hunian masyarakat maupun sarana dan prasarana yang ada tidak sesuai dengan standar permukiman perkotaan, baik standar kebutuhan, kepadatan bangunan, persyaratan rumah sehat, kebutuhan sarana air bersih, sanitasi maupun persyaratan kelengkapan prasarana jalan, ruang terbuka, serta kelengkapan fasilitas sosial lainnya. Apabila kawasan permukiman tersebut dibiarkan tumbuh tidak terencana maka semakin kumuh dan dapat memperburuk kondisi lingkungan perkotaan secara keseluruhan.

Kampung Braga merupakan salah satu 'kampung' yang termasuk permukiman kumuh di pusat kota Bandung. Kawasan ini termasuk dalam termasuk dalam kategori kawasan yang memiliki tingkat kekumuhan berat dan kualitas kawasan yang rendah. Dari karakter fisik dan aspek legalitasnya, di kawasan Kampung Braga ini terdapat 2 (dua) kategori permukiman kumuh,yaitu: 1) slum yang merupakan kawasan kumuh tetapi diakui absah sebagai kawasan permukiman, misalnya hunian yang di bangun di Kampung Braga sesuai peruntukan namun mempunyai kepadatan yang tinggi dan tidak teratur; 2) squatter settlement yang merupakan pemukiman kumuh infomal dengan menempati lahan yang tidak ditetapkan untuk kawasan hunian, misalnya: hunian terbangun di pinggiran sungai Cikapundung. Oleh karena itu, perlu dilakukan transformasi atau penataan kawasan Kampung Braga menjadi permukiman yang lebih layak huni sehingga nilai kualitas kawasan dan kualitas hidup masyarakat meningkat, terutama golongan bermasyarakat rendah atau kurang mampu yang tinggal di kawasan tersebut.

Penataan kawasan permukiman kumuh Kampung Braga ini dapat dikaitkan dengan peremajaan kota dengan mengembangkan konsep pembangunan lingkungan permukiman yang terpadu dengan melibatkan partisipasi masyarakat atau pemilik tanah dan memprioritaskan menampung penghuni lama atau pemilik tanah di kawasan Kampung Braga. Peremajaan kota merupakan proses perubahan fisik, perubahan fungsi, dan proses perubahan intensitas pemakaian suatu lahan dan bangunan sebagai upaya peningkatan kualitas sosial ekonomi bagian kota (Couch 1990). Penataan kawasan kumuh tidak dapat dilakukan secara sepihak, melainkan harus merupakan upaya terpadu yang saling mendukung dan saling bersinergi dalam mencapai sasaran optimal bersama yang ingin di capai. Untuk itu, diperlukan pendekatan dan kesinambungannya yang berlandaskan pembangunan bertumpu partisipasi masyarakat.

Salah satu pendekatan untuk penataan kawasan melalui di Kampung Braga adalah penyesuaian ulang lahan (land readjustment). Secara prinsip, penyesuaian ulang lahan tidak diarahkan untuk memperluas persil, namun untuk meningkatkan kualitas kawasan dan memaksimalkan nilai kawasan. Secara umum, transformasi atau penataan kawasan 
Kampung Braga yang ditawarkan kepada masyarakatdiarahkan untuk memecahkan persoalan kawasan kumuh dengan penataan persil (lot) permukiman yang tidak teratur dan perubahan penggunaan lahan melalui peningkatan nilai lahan dan potensi 'recaptures' nilai tambah yang diciptakan yang dapat diterapkan untuk mensubsidi pembangunan sarana dan prasarana, serta penyediaan perumahan untuk masyarakat berpenghasilan rendah (MBR) atau miskin yang layak huni (Doebele, 2002 dalam Li dan Li 2007; Schrock 2012; Turk 2008; Turk dan Altes 2012; Mittal 2014). Secara gagasan tersebut dapat dijelaskan sebagai berikut: (1) penyesuaian ulang lahan yang akan dilakukan merupakan penataan bentuk persil (lot) dan penyatuan semua bidang tanah serta perencanaan tata letal persil di kawasan permukiman kumuh yang tidak teratur; (2) penyediaan sarana dan prasarana yang memenuhi standar permukiman kota seperti: jalan lingkungan, drainase, pembuangan limbah, air bersih, ruang terbuka hijau dan sarana publik lainnya; (3) pembiayaan secara swadana melalui Kontribusi lahan sebagai bentuk partisipasi pemilik lahan dengan mengurangi sebagaian luasan lahan dari seluruh setiap persil (lot) sekitar 30\% - $40 \%$ dari luas lahan sesuai consensus bersama. Kontribusi lahan digunakan untuk penyediaan sarana dan prasarana dan lahan cadangan yang dapat dikomersialkan untuk membiayai kegiatan penyesuaian ulang lahan; (4) membagi tanah kembali (pengembalian) kepada pemilik aslinya dengan ukuran yang lebih kecil dari sebelumnya atau pengembalian dalam bentuk konversi ruang bangunan vertikal (satuan rumah susun atau apartemen); (5) penyediaan perumahan (hunian) yang terjangkau untuk masyarakat berpenghasilan rendah (MBR) atau miskin yang layak huni dengan memprioritaskan menampung penghuni lama yang selama ini tinggal di kawasan Braga; (6) meminimal perpindahan kepemilikan dan relokasi melalui redistribusi kembali lahan kepada pemilik lahan dan melindungi modal sosial masyarakat di kawasan Kampung Braga. Kondisi tersebut dapat diilustrasikan dalam Gambar 1.

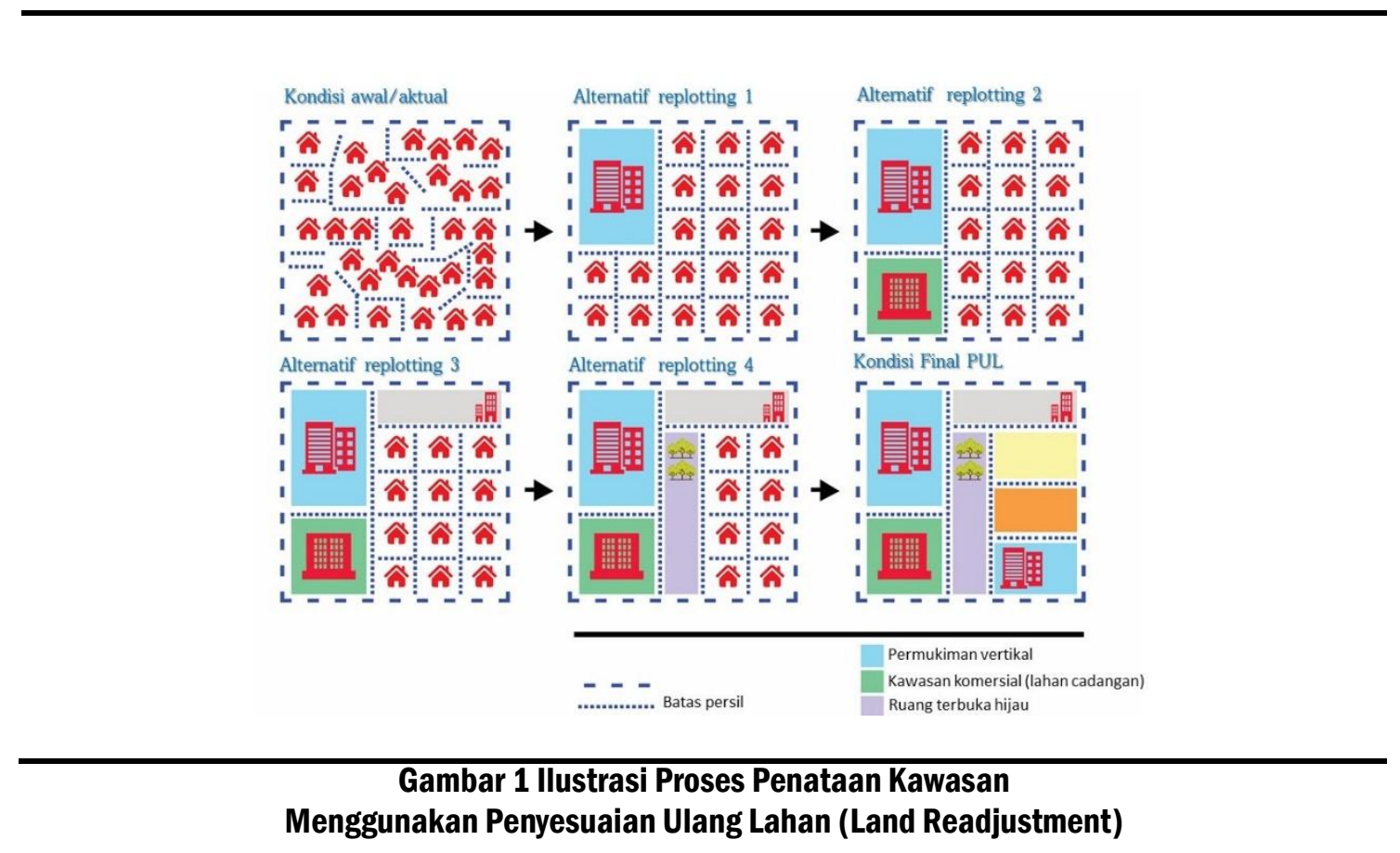

Partisipasi masyarakat dalam proses transformasi kawasan tersebut membutuhkan suatu prakondisi yang mendukung. Salah satu yang penting adalah kesiapan masyarakat itu sendiri. Untuk mendapatkan gambaran kesiapan masyarakat, kita perlu mendapatkan informasi mengenai preferensi masyarakat atas gagasan/rencana transformasi atau 
penataan kawasan yang akan dilakukan. Secara umum preferensi tersebut terkait dengan gambaran sejauhmana dukungan maupun resistensi yang ada di masyarakat. Pemahaman atas preferensi dapat membawa kita pada proses-proses atau tahapan yang dibutuhkan untuk membangun atau memastikan kesiapan masyarakat. Untuk itu, penelitian ini bertujuan untuk menganalisis preferensi dan potensi partisipatif masyarakat untuk kepentingan perencanaan atas gagasan/rencana penataan kawasan menggunakan penyesuaian ulang lahan di kawasan Kampung Braga.

\section{METODE}

\section{Kerangka Analisis}

Transformasi atau penataan kawasan Kampung Braga yang ditawarkan kepada masyarakat diarahkan untuk memecahkan persoalan kawasan kumuh dengan penataan persil (lot) permukiman dan perubahan penggunaan lahan melalui peningkatan nilai lahan. Gagasan atau rencana penataan tersebut tidak dapat dilakukan secara sepihak, melainkan harus merupakan upaya terpadu yang saling mendukung dan saling bersinergi dalam mencapai sasaran optimal bersama yang ingin di capai. Untuk itu, diperlukan pendekatan dan kesinambungannya yang berlandaskan pembangunan bertumpu pada masyarakat (partisipasi). Berdasarkan hal itu, analisis dilakukan dengan kerangka sebagaimana disajikan pada Gambar 2.

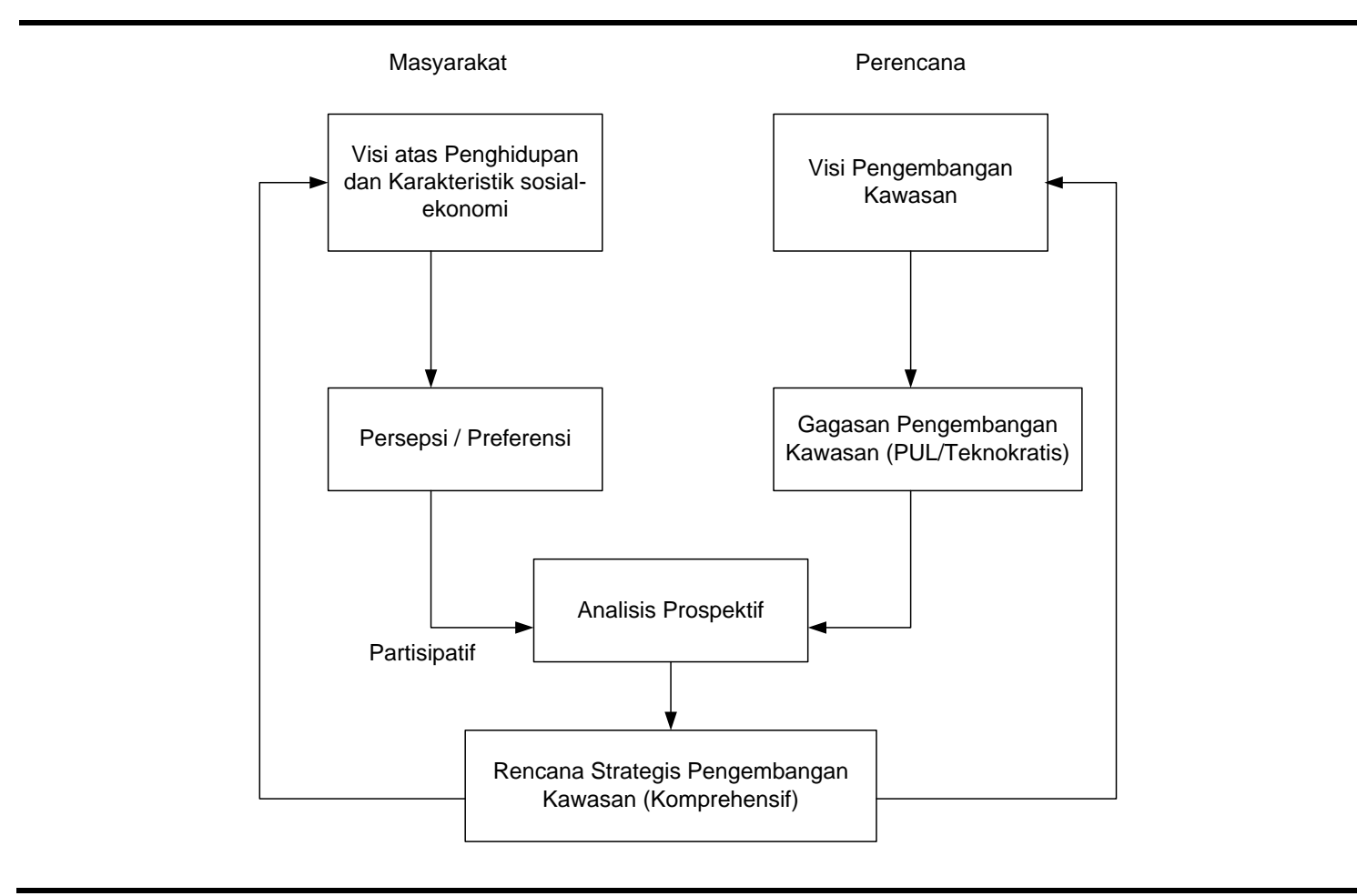

Gambar 2 Kerangka analisis

Berdasarkan Gambar 2 diatas, masyarakat memiliki preferensi atas isu-isu yang terkait dengan gagasan/rencana penataan kawasan yang ditawarkan. Preferensi maupun kepentingan masyarakat atas gagasan atau rencana yang ditawarkan tersebut dapat dipetakan dalam suatu kerangka analisis prospektif partisipatif. Dengan pendekatan ini, masyarakat diberikan kesempatan untuk berpartisipasi secara aktif dalam membayangkan 
atau mendeskripsikan skenario-skenario yang mungkin terjadi di masa depan. Secara sederhana, gambaran umum analisis prospektif yang dilakukan adalah sebagaimana gambar 3 berikut.

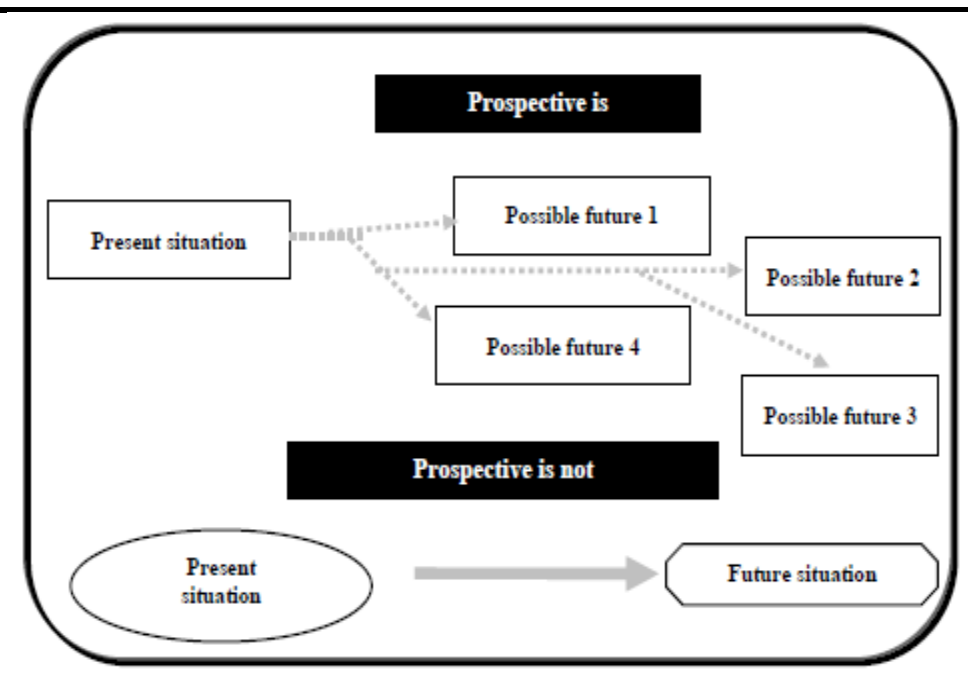

Gambar 3 Analisis Prospektif (CAPSA, 2004)

Analisis prospektif partisipatif merupakan adaptasi dari berbagai metode komprehensif yang dikemas dalam suatu kerangka kerja operasional yang komprehensif dan cepat. Sifat kognitif dari metode tersebut adalah berupa tipologi yang difokuskan pada interaksi yang mampu menghasilkan suatu konsensus dari interaksi antara pemangku kepentingan (stakeholder), yang dapat digunakan untuk kepentingan perencanaan. Metode ini didasarkan pada beberapa prinsip, yaitu partisipasi, transparansi, konsistensi, keefektifan, relevansi, dapat diulang, beralasan, dan peningkatan kapasitas stakeholders (Godet dan Roubelat, 1998; Bourgeois dan Jesus, 2004). Tingkat kedalaman pelibatan stakeholders dalam analisis prospektif partisipatif dapat memenuhi tingkat partisipasi kolegiat sebagaimana perspektif Bigg (1989) dalam Cornwall dan Jewkes (1995); serta termasuk dalam tipologi partisipasi interaktif menurut (Brown et al. 2001). Dengan analisis prospektif partisipasif ini, gagasan atau rencana penataan kawasan yang telah disusun sebelumnya diharapkan menjadi lebih lengkap dan komprehensif.

\section{Gambaran Lokasi Penelitian}

Lokasi penelitian ini adalah kawasan Kampung Braga yang secara administratif kawasan ini berada di Kelurahan Braga Kecamatan Sumur Bandung. Kampung ini mempunyai dua Rukun Warga (RW), yaitu RW 04 terdiri dari enam Rukun Tetangga (RT) dan RW 08 terdiri dari enam Rukun Tetangga (RT). Jumlah penduduk yang menghuni Kampung Braga sekitar 2,368 jiwa dengan tingkat kepadatan penduduk yang tinggi 0.12 jiwa $/ \mathrm{m}^{2}$ (di atas $0.05 \mathrm{jiwa} / \mathrm{m}^{2}$ ). Hasil studi sebelumnya menunjukkan bahwa di dalam kawasan Kampung Braga tersebut, terdapat kawasan pemukiman yang tidak teratur dan padat penduduk seluasan $+19750 \mathrm{~m} 2(31,7 \%$ dari total kawasan) mempunyai tingkat kekumuhan tinggi (dengan nilai totalnya 88), dengan kualitas kawasan yang rendah (indeks kualitas ruang sebesar 0.25) (Wihadanto, et.al 2017). Dengan kondisi demikian, kawasan tersebut memerlukan transformasi untuk mengurangi tingkat kekumuhan dan meningkatkan 
kualitas kawasan. Kawasan permukiman kumuh tersebut menjadi lokus penelitian ini untuk menerapkan penyesuaian ulang lahan (Gambar 4).

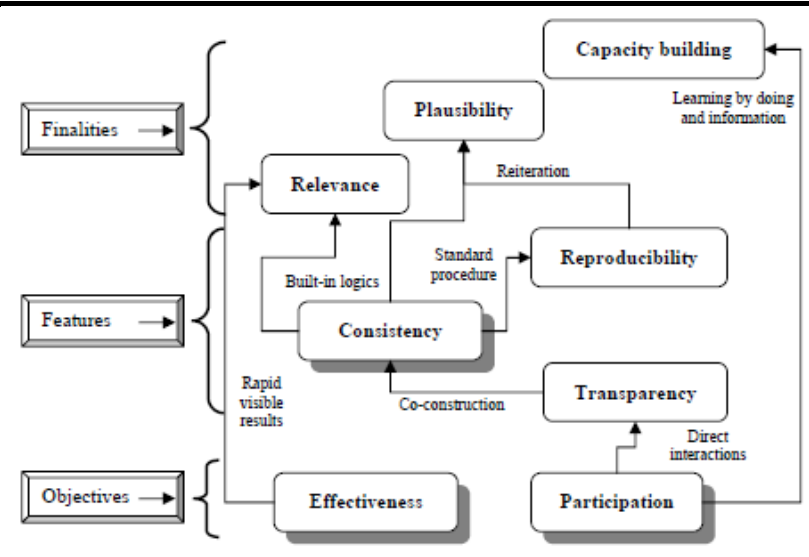

Gambar 4 Kerangka Prinsip Analisis Prospektif Partisipatif (CAPSA, 2004)

\section{Gambaran Karakteristik Sosial-Ekonomi Masyarakat}

Penghuni Kampung Braga memiliki karakteristik yang beragam tidak hanya penduduk asli atau keluarga yang secara turun temurun tinggal di kampung tersebut namun juga para pendatang yang umumnya bekerja atau mempunyai aktivitas ekonomi disekitar kawasan ini. Secara sosial ekonomi, karakteristik penghuni Kampung Braga sebagian besar bekerja sebagai wiraswasta atau pedagang dan pekerja swasta (Tabel 1).

Tabel 1 Karakteristik Penghuni

\begin{tabular}{lll}
\hline \multicolumn{1}{c}{ Karakteritik } & \multicolumn{1}{c}{$\begin{array}{c}\text { Kondisi } \\
\text { Actual }\end{array}$} & \multicolumn{1}{c}{ Keterangan } \\
\hline Pekerjaan kepala & (1) Wiraswasta/ & \\
rumah tangga & Pedagang: 46.2\%; (2) Karyawan swasta: 22.3\%; & \\
& (3) Buruh:14.4\%; (4) Ibu rumah tangga: & \\
& 10.2\%;(4)Pensiun/tidak bekerja: 4.9\%; (5) PNS: & \\
& 2\%. & \\
Penghasilan KK & $(1)<500$ 000.00: 7.4\%; (2) 500 000.00-1500 & Standar UMR Kota Bandung \\
perbulan: & 000.00: 55.3\%; (3)> 1500 000.00: 35.4\%;(4) & Rp. 2 843662.00 \\
& Tidak menjawab: $1.9 \%$ & \\
Tingkat pendidikan & (1) SD: 23.3\%; (2) SMP: 13.8\%; (3) SMA: & \\
& 55.1\% ;(4) Diploma \& S1: 3.3\%; (5) Tidak & \\
& sekolah: 4.6\% & \\
\hline
\end{tabular}

\section{Teknik Pengambilan Data dan Sampel}

Data didapatkan melalui proses observasi, wawancara, dan diskusi terbatas (FGD). Ada 30 narasumber yang merupakan perwakilan dan tokoh masyarakat penghuni kampung Braga. Wawancara mendalam (in-depth interview) kepada para tokoh masyarakat dan warga kawasan Kampung Braga dipilih secara secara purposive. Hasil dari wawancara dan FGD tersebut selanjutnya dijadikan input bagi proses Analisis Prospektif Partisipatif untuk memetakan kebutuhan / preferensi masyarakat atas gambaran masa depan dikaitkan dengan gagasan atau rencana penataan kawasan yang ditawarkan. 


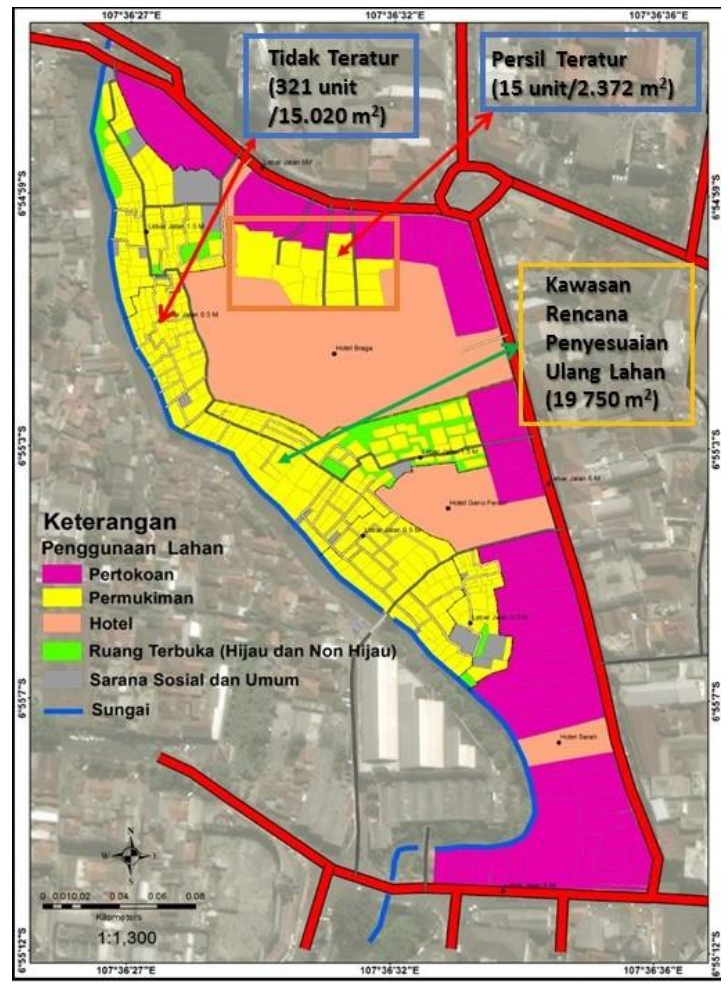

Sumber: Citra satelit dan diolah dari hasil survei

\section{Gambar 5 Kawasan Rencana Penyesuaian Ulang Lahan(Land Readjustment)di Kampung Braga}

\section{Metode analisis data}

Dalam penelitian ini, berdasarkan hasil dari wawancara dan FGD disajikan gambaran umum preferensi masyarakat terkait dengan rencana penataan kawasan Kampung Braga. Dalam gambaran umum dibahas atau dideskripsikan secara kualitatif preferensi masyarakat atas berbagai isu yang berhasil digali dan terkait dengan rencana penataan kawasan Kampung Braga, penelitian ini menggunakan analisis prospektif partisipatif (Bourgeois dan Jesus 2004):

\section{HASIL DAN PEMBAHASAN}

\section{Deskripsi Preferensi Masyarakat}

Berdasarkan hasil wawancara mendalam kepada beberapa kelompok/wakil masyarakat, serta menggunakan kerangka yang telah diuraikan diatas, analisis preferensi masyarakat disusun menurut dua kategori masyarakat, yaitu (1) kelompok masyarakat pemilik lahan; dan (2) kelompok masyarakat pemilik bangunan. Pada setiap kelompok masyarakat, gambaran preferensi terhadap gagasan/rencana penataan kawasan Kampung Braga secara umum disajikan pada Tabel 2 berikut.

Sementara itu, pada kedua kelompok masyarakat, gambaran preferensi disajikan berdasarkan 4 isu berikut: (1) kondisi kawasan/pemukiman saat ini; (2) sistem kelembagaan/pengorganisasian yg mengatur kehidupan bersama di kawasan yg berlaku saat ini; (3) pengalaman selama ini dalam kaitan dengan gagasan/rencana penataan kawasan yang pernah ada sebelumnya; (4) harapan ke depan dengan adanya rencana penataan ini. Gambaran tersebut dapat kita lihat sebagai sudut pandang yang 
melatarbelakangi atau menjelaskan sikap atau preferensi masyarakat terhadap rencana penataan kawasan Kampung Braga. (lihat Tabel 3)

Tabel 2 Preferensi Pemilik Lahan dan Pemilik Bangunan terhadap Rencana Penataan Kawasan Kampung Braga

\begin{tabular}{|c|c|c|c|}
\hline \multirow{3}{*}{$\begin{array}{c}\text { Kategori } \\
\text { Masyarakat } \\
\text { Pemilik Lahan }\end{array}$} & \multicolumn{3}{|c|}{ Preferensi atas rencana penataan } \\
\hline & Positif & Ragu-ragu & Negatif \\
\hline & $\begin{array}{l}\text { Mendukung atas rencana penataan, } \\
\text { dengan harapan ada peningkatan } \\
\text { nilai lahan yang didorong oleh } \\
\text { peningkatan kualitas kawasan. } \\
\text { Melihat proses penataan sebagai } \\
\text { opportunity untuk membereskan } \\
\text { masalah penguasaan tanah mereka } \\
\text { selama ini }\end{array}$ & $\begin{array}{l}\text { Meragukan keberhasilan } \\
\text { rencana penataan ini. } \\
\text { Terutama dalam hal } \\
\text { bagaimana } \\
\text { menyambungkannya } \\
\begin{array}{l}\text { dengan keinginan } \\
\text { masyarakat }\end{array} \text { penghuni } \\
\text { (yang } \\
\text { bangunan) }\end{array}$ & $\begin{array}{lr}\text { Kurang } & \text { tidak } \\
\text { tertarik } & \text { untuk } \\
\text { berpartisipasi. } & \\
\text { Cenderung melepas } \\
\text { lahan yang dimiliki } \\
\text { dengan rarga } \\
\text { wajar/pantas. }\end{array}$ \\
\hline $\begin{array}{l}\text { Pemilik } \\
\text { Bangunan }\end{array}$ & $\begin{array}{l}\text { Dukungan atas rencana penataan, } \\
\text { dengan harapan adanya kejelasan } \\
\text { atas status penguasaan / pemilikan } \\
\text { bangunan; serta kondisi lingkungan } \\
\text { dan sosial-ekonomi yang lebih baik. } \\
\text { Menekankan proses penataan yang } \\
\text { adil dan transparan, serta } \\
\text { komunikasi yang baik dengan } \\
\text { masyarakat. }\end{array}$ & $\begin{array}{l}\text { Tidak terlalu } \\
\text { mementingkan rencana } \\
\text { penataan. Yang penting, } \\
\text { bangunan yang telah } \\
\text { dimiliki (dikuasai) saat ini } \\
\text { tidak hilang (diganti secara } \\
\text { wajar) walaupun harus } \\
\text { dilakukan relokasi (pindah) }\end{array}$ & $\begin{array}{l}\text { Sikap negatif atau } \\
\text { pesimis berdasarkan } \\
\text { pengalaman } \\
\text { sebelumnya, bahwa } \\
\text { proses penataan } \\
\text { akan berjalan secara } \\
\text { adil dan transparan. }\end{array}$ \\
\hline
\end{tabular}

Tabel 3 Preferensi Masyarakat (Pemilik Lahan) Menurut 4 Isu di Masyarakat Kampung Braga

\begin{tabular}{|c|c|c|c|}
\hline \multirow{2}{*}{$\begin{array}{l}\text { Aspek-aspek terkait } \\
\text { penataan }\end{array}$} & \multicolumn{3}{|c|}{ Preferensi umum atas rencana penataan } \\
\hline & Positif & Ragu-ragu & Negatif \\
\hline $\begin{array}{l}\text { Kondisi } \\
\text { hunian }\end{array}$ & $\begin{array}{l}\text { Lingkungan yang secara } \\
\text { fisik tidak/kurang nyaman } \\
\text { dan kurang sehat. Perlu } \\
\text { penataan. Lokasi strategis. }\end{array}$ & $\begin{array}{l}\text { Lingkungan yang secara } \\
\text { fisik tidak/kurang } \\
\text { nyaman dan kurang } \\
\text { sehat. Perlu penataan. } \\
\text { Lokasi strategis. }\end{array}$ & $\begin{array}{l}\text { Lingkungan yang secara } \\
\text { fisik tidak/kurang } \\
\text { nyaman dan kurang } \\
\text { sehat. Perlu penataan. } \\
\text { Lokasi strategis. }\end{array}$ \\
\hline $\begin{array}{l}\text { Kondisi } \\
\text { pengorganisasian } \\
\text { pengelolaan kawasan } \\
\text { / hunian }\end{array}$ & $\begin{array}{l}\text { Masyarakat penghuni } \\
\text { kawasan Kampung Braga } \\
\text { umumnya menyewa } \\
\text { kepada pemilik lahan, dan }\end{array}$ & $\begin{array}{lr}\text { Masyarakat } & \text { penghuni } \\
\text { kawasan } & \text { Kampung } \\
\text { Braga } & \text { umumnya } \\
\text { menyewa } & \text { kepada }\end{array}$ & $\begin{array}{lr}\text { Masyarakat } & \text { penghuni } \\
\text { kawasan } & \text { Kampung } \\
\text { Braga } & \text { umumnya } \\
\text { menyewa } & \text { kepada }\end{array}$ \\
\hline & $\begin{array}{l}\text { hubungan sewa-menyewa } \\
\text { ini sudah berlangsung } \\
\text { lama, dan turun-temurun }\end{array}$ & $\begin{array}{l}\text { pemilik lahan, dan } \\
\text { hubungan } \\
\text { menyewa ini sewa- } \\
\text { berlangsung lama, dan } \\
\text { turun-temurun }\end{array}$ & $\begin{array}{l}\text { pemilik lahan, dan } \\
\text { hubungan sewa- } \\
\text { menyewa ini sudah } \\
\text { berlangsung lama, dan } \\
\text { turun-temurun }\end{array}$ \\
\hline 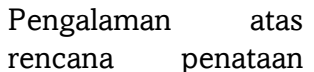 & \begin{tabular}{llr} 
Pernahada & \multicolumn{2}{c}{ beberapa } \\
rencana & proyek di
\end{tabular} & $\begin{array}{l}\text { pernah ada beberapa } \\
\text { rencana proyek di }\end{array}$ & $\begin{array}{l}\text { pernah ada beberapa } \\
\text { rencana proyek di }\end{array}$ \\
\hline & $\begin{array}{llr}\text { Kampung Braga, namun } \\
\text { tidak } \\
\text { perkembangannya }\end{array}$ & $\begin{array}{l}\text { Kampung Braga, namun } \\
\text { tidak jelas } \\
\text { perkembangannya }\end{array}$ & $\begin{array}{l}\text { Kampung Braga, namun } \\
\text { tidak jelas } \\
\text { perkembangannya }\end{array}$ \\
\hline $\begin{array}{l}\text { Ekspektasi } \\
\text { penataan }\end{array}$ & $\begin{array}{l}\text { Lingkungan lebih baik, } \\
\text { fasilitas ditingkatkan, } \\
\text { kepastian/jaminan } \\
\text { pemilikan lahan, nilai lahan } \\
\text { meningkat }\end{array}$ & $\begin{array}{lr}\text { Meragukan penataan } \\
\text { akan berjalan baik, } \\
\text { karena tidak akan } \\
\text { nyambung dengan } \\
\text { masyarakat penghuni } \\
\end{array}$ & $\begin{array}{l}\text { Kepemilikan atas lahan } \\
\text { dapat tetap dijamin, } \\
\text { dengan nilai lahan naik. } \\
\text { Jika perlu, dapat dijual } \\
\text { dengan relatif mudah. } \\
\end{array}$ \\
\hline
\end{tabular}


Tabel 4 Pandangan Masyarakat (Pemilik Bangunan) Menurut 4 Isu di Masyarakat Kampung Braga

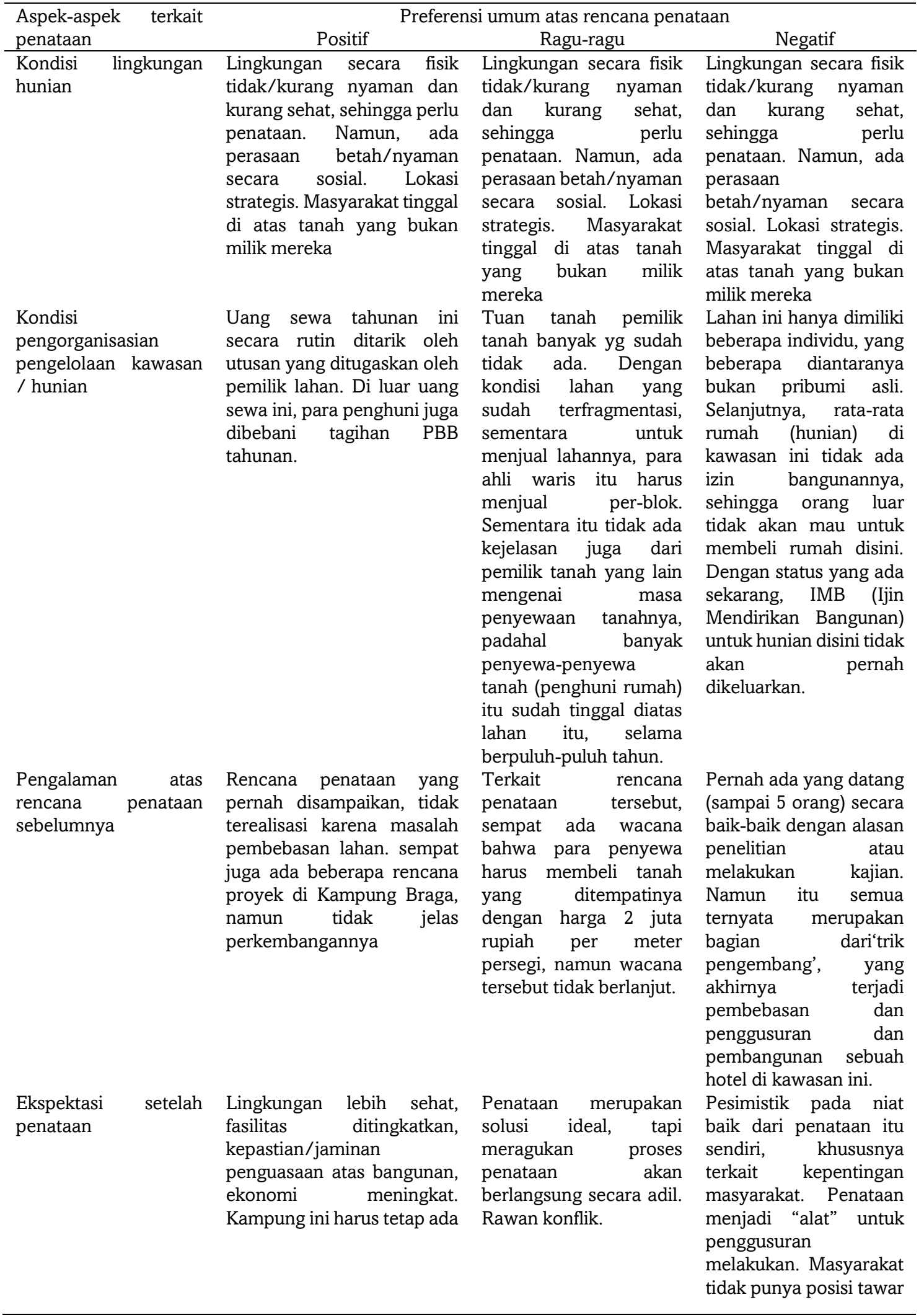




\section{Analisis Prospektif Partisipatif}

\section{Definisi sistem dan Identifikasi Variabel}

Dalam analisis prospektif partisipatif, pada tahap awal dirumuskan secara jelas definisi atau cakupan sistem yang menjadi fokus. Dalam hal ini cakupan sistem adalah penataan kawasan Kampung Braga melalui metode Penyesuaian Ulang Lahan (land readjustment), dengan batas wilayah sebagaimana telah disampaikan pada bagian awal. Dengan rumusan sistem sebagaimana diatas, berdasarkan hasil wawancara dan FGD, telah diidentifikasi variabelvariabel yang dianggap akan mempengaruhi kinerja sistem ke depan, sebagai berikut (Tabel $5)$.

\section{Tabel 5 Hasil Identifikasi Awal Variabel-Variabel}

\begin{tabular}{|c|c|c|}
\hline No & Variabel & Definisi/ Deskripsi \\
\hline 1 & Nilai lahan & $\begin{array}{l}\text { Nilai ekonomi (potensi harga pasar) dari lahan yang menjadi objek } \\
\text { penataan }\end{array}$ \\
\hline 2 & Nilai ekonomi lokasi & Nilai ekonomi yang dapat dihasilkan dari keunggulan lokasi \\
\hline 3 & $\begin{array}{l}\text { Kejelasan Penguasaan atau } \\
\text { pemilikan lahan/bangunan } \\
\text { (tenurial system) }\end{array}$ & $\begin{array}{l}\text { Kejelasan atas pihak-pihak beserta status dalam kaitannya dengan } \\
\text { penguasaan/kepemilikan lahan/bangunan di kawasan objek penataan }\end{array}$ \\
\hline 4 & Kualitas Kawasan & $\begin{array}{l}\text { Aspek-aspek dalam kawasan yang terkait dengan kualitas kehidupan } \\
\text { (livelihood) masyarakat dalam objek penataan }\end{array}$ \\
\hline 5 & $\begin{array}{l}\text { Ketersambungan antara } \\
\text { perencanaan dengan } \\
\text { keinginan/kebutuhan masyarakat }\end{array}$ & $\begin{array}{l}\text { Konsistensi antara hal-hal yang diatur dalam perencanaan penataan } \\
\text { dengan kebutuhan masyarakat terhadap penataan tersebut. Sejauhmana } \\
\text { kebutuhan tersebut dapat diakomodasi dalam proses penataan }\end{array}$ \\
\hline 6 & Insentif & $\begin{array}{l}\text { Mekanisme distribusi benefit (manfaat) diantara para pihak terkait dalam } \\
\text { proses penataan kawasan }\end{array}$ \\
\hline 7 & Kompensasi & $\begin{array}{l}\text { Mekanisme pemberian manfaat (benefit) dikaitkan dengan tingkat } \\
\text { distribusi para pihak dalam proses penataan }\end{array}$ \\
\hline 8 & Transparansi & $\begin{array}{l}\text { Aspek aksesibilitas para pihak atas informasi serta proses klarifikasinya, } \\
\text { terkait proses penataan kawasan }\end{array}$ \\
\hline 9 & Komunikasi & $\begin{array}{l}\text { Mekanisme aliran informasi diantara para pihak, terkait dengan proses } \\
\text { penataan }\end{array}$ \\
\hline 10 & Pengalaman masa lalu & $\begin{array}{l}\text { Informasi kejadian di masyarakat terkait dengan proses penataan } \\
\text { kawasan di masa lalu, baik yang dipersepsikan negative maupun positif }\end{array}$ \\
\hline 11 & Kelembagaan/Pengorganisasian & $\begin{array}{l}\text { Pengaturan relasi para pihak yang berkepentingan, terkait dengan } \\
\text { penataan }\end{array}$ \\
\hline 12 & $\begin{array}{l}\text { Posisi tawar masyarakat dalam } \\
\text { proses penataan }\end{array}$ & $\begin{array}{l}\text { Kekuatan masyarakat untuk mempengaruhi atau mengintervensi } \\
\text { berbagai aspek dalam proses penataan }\end{array}$ \\
\hline 13 & $\begin{array}{l}\text { Konsistensi dalam proses } \\
\text { penataan }\end{array}$ & $\begin{array}{l}\text { Kesesuaian, baik antara perencanaan dengan pelaksanaan, maupun } \\
\text { antara azas/prinsip yang disepakati dengan proses manajerialnya }\end{array}$ \\
\hline 14 & Potensi konflik & Tingkat kecenderungan untuk terjadinya konflik \\
\hline
\end{tabular}

\section{Analisis Pengaruh dan Kebergantungan Antar Variabel}

Selanjutnya, dilakukan analisis tingkat pengaruh (influence) dan kebergantungan (dependence) antar variabel-variabel diatas. Hasil analisis tersebut disajikan dalam 3 matriks: (1) matriks tingkat pengaruh dan kebergantungan langsung; (2) matriks tingkat pengaruh dan kebergantungan tidak langsung; dan (3) matriks tingkat pengaruh dan kebergantungan total (langsung dan tidak langsung). Tabel 6 menyajikan matriks total.

Valuasi pengaruh langsung ataupun tidak langsung dari masing-masing variabel terhadap variabel lainnya, menggunakan skala dari " $0=$ tidak ada pengaruh" sampai " 3 = berpengaruh sangat kuat". Sedangkan untuk pengaruh total (langsung dan tidak langsung) dihitung dengan menjumlahkan valuasi pengaruh langsung dan tidak langsung. Matriks tersebut dibaca sebagai berikut: Elemen matriks $(i, j)=$ valuasi pengaruh variabel i terhadap variabel $\mathrm{j}$; atau dapat pula dibaca sebagai ketergantungan variabel $\mathrm{j}$ terhadap variabel $\mathrm{i}$. 
Apabila dijumlahkan seluruh elemen pada baris i dapat dibaca sebagai total pengaruh yang diberikan oleh variabel i. Sedangkan jika dijumlahkan seluruh elemen pada kolom j, dibaca sebagai total ketergantungan dari variabel $\mathrm{j}$ terhadap variabel-variabel yang lainnya.

Tabel 6. Matriks Hasil Analisis Pengaruh dan Kebergantungan Antar Variabel:

Total (Langsung dan Tidak Langsung)

\begin{tabular}{|c|c|c|c|c|c|c|c|c|c|c|c|c|c|c|}
\hline \multirow{2}{*}{$\begin{array}{c}\text { Dependence } \\
\text { (Ketergantungan) }\end{array}$} & \multicolumn{14}{|c|}{$\leftarrow$ Influence (Pengaruh) $\rightarrow$} \\
\hline & 1 & 2 & 3 & 4 & 5 & 6 & 7 & 8 & 9 & 10 & 11 & 12 & 13 & 14 \\
\hline 1 & 5.0 & 3.3 & 4.0 & 4.0 & 1.3 & 1.3 & 0.7 & 4.0 & 1.3 & 1.3 & 4.0 & 5.0 & 3.3 & 4.0 \\
\hline 2 & 4.3 & 1.3 & 4.0 & 3.3 & 1.3 & 1.3 & 0.7 & 3.3 & 2.3 & 0.7 & 3.3 & 4.3 & 1.3 & 4.0 \\
\hline 3 & 4.0 & 1.3 & 2.3 & 3.3 & 1.3 & 1.3 & 0.7 & 2.3 & 3.3 & 0.7 & 2.3 & 4.0 & 1.3 & 2.3 \\
\hline 4 & 2.0 & 2.0 & 4.0 & 3.0 & 0.7 & 0.7 & 0.7 & 3.0 & 1.3 & 0.3 & 2.0 & 2.0 & 2.0 & 4.0 \\
\hline 5 & 2.0 & 1.3 & 0.7 & 0.7 & 2.0 & 2.0 & 0.3 & 2.0 & 0.7 & 2.7 & 2.0 & 2.0 & 1.3 & 0.7 \\
\hline 6 & 2.3 & 0.7 & 1.3 & 2.3 & 1.3 & 1.3 & 1.3 & 2.3 & 2.7 & 0.7 & 3.3 & 2.3 & 0.7 & 1.3 \\
\hline 7 & 1.3 & 0.7 & 3.3 & 1.3 & 1.3 & 1.3 & 1.7 & 2.3 & 3.3 & 0.7 & 3.3 & 1.3 & 0.7 & 3.3 \\
\hline 8 & 1.3 & 3.0 & 2.3 & 2.3 & 3.0 & 5.0 & 1.0 & 5.0 & 3.0 & 3.0 & 5.0 & 1.3 & 3.0 & 2.3 \\
\hline 9 & 2.0 & 3.3 & 2.0 & 2.3 & 4.3 & 3.0 & 1.7 & 5.0 & 3.0 & 3.0 & 5.0 & 2.0 & 3.3 & 2.0 \\
\hline 10 & 1.3 & 1.7 & 1.7 & 1.7 & 1.0 & 2.3 & 0.3 & 2.3 & 1.7 & 0.7 & 3.0 & 1.3 & 1.7 & 1.7 \\
\hline 11 & 2.3 & 3.3 & 1.7 & 2.3 & 4.0 & 4.0 & 1.7 & 2.0 & 2.3 & 2.3 & 4.0 & 2.3 & 3.3 & 1.7 \\
\hline 12 & 1.3 & 1.3 & 3.3 & 2.7 & 4.0 & 4.0 & 0.7 & 4.0 & 1.3 & 2.3 & 4.0 & 1.3 & 1.3 & 3.3 \\
\hline 13 & 2.0 & 2.7 & 0.7 & 0.7 & 2.0 & 2.0 & 0.3 & 2.0 & 1.7 & 1.3 & 2.0 & 2.0 & 2.7 & 0.7 \\
\hline 14 & 4.0 & 2.3 & 2.3 & 2.3 & 2.0 & 3.3 & 0.7 & 3.3 & 1.7 & 1.7 & 2.0 & 4.0 & 2.3 & 2.3 \\
\hline
\end{tabular}

\section{Peta Kekuatan Variabel}

Berdasarkan matriks diatas, berikut ini disampaikan hasil perhitungan skor kekuatan variabel global tertimbang (kolom 5), yang digunakan untuk menentukan peringkat variabel. Variabel yang memiliki skor tertinggi merupakan variabel terkuat, yang memiliki pengaruh tertinggi dan ketergantungan terendah.

Tabel 7 Hasil Perhitungan Skor Kekuatan Variabel (Langsung dan Tidak Langsung)

\begin{tabular}{|c|c|c|c|c|}
\hline \multirow[b]{2}{*}{$\begin{array}{c}\text { Variables } \\
\text { (1) }\end{array}$} & \multicolumn{2}{|c|}{ Weighted } & \multirow[b]{2}{*}{$\begin{array}{c}\text { Global Strength } \\
(4)\end{array}$} & \multirow{2}{*}{$\begin{array}{c}\text { Weighted } \\
\text { Global Strength } \\
(5)\end{array}$} \\
\hline & $\begin{array}{c}\text { Global Influence } \\
\text { (2) }\end{array}$ & $\begin{array}{l}\text { Global Dependence } \\
\text { (3) }\end{array}$ & & \\
\hline 1 & 1.21 & 1.19 & 0.04 & 1.20 \\
\hline 2 & 1.09 & 1.13 & 0.04 & 1.06 \\
\hline 3 & 1.01 & 0.72 & 0.04 & 1.16 \\
\hline 4 & 0.98 & 1.13 & 0.03 & 0.90 \\
\hline 5 & 0.67 & 0.90 & 0.02 & 0.56 \\
\hline 6 & 0.80 & 1.07 & 0.02 & 0.67 \\
\hline 7 & 0.80 & 1.03 & 0.02 & 0.68 \\
\hline 8 & 1.26 & 0.95 & 0.05 & 1.43 \\
\hline 9 & 1.34 & 1.05 & 0.05 & 1.48 \\
\hline 10 & 0.73 & 0.39 & 0.03 & 0.94 \\
\hline 11 & 1.21 & 1.37 & 0.04 & 1.12 \\
\hline 12 & 1.08 & 0.95 & 0.04 & 1.14 \\
\hline 13 & 0.70 & 0.68 & 0.03 & 0.70 \\
\hline 14 & 1.12 & 1.44 & 0.03 & 0.96 \\
\hline
\end{tabular}

Berdasarkan tabel diatas maka dapat diidentifikasi beberapa variabel yang dianggap memiliki pengaruh yang relatif kuat dalam sistem, yaitu: variabel 9 (komunikasi); variabel 8 (transparansi); variabel 1 (nilai lahan); variabel 3 (kejelasan penguasaan dan pemilikan); variabel 12 (posisi tawar masyarakat dalam proses penataan); variabel 11 (kelembagaan atau keorganisasian); dan variabel 2 (nilai ekonomi lokasi).

Hasil perhitungan pada diatas, dipetakan pada gambar 6 berikut: (menggunakan data pada kolom 2 dan kolom 3). Grafik total (langsung dan tidak langsung), juga 
menunjukkan tingkat kekuatan variabel. Kuadran I (kiri atas) merupakan wilayah variabel penggerak (memiliki daya pengaruh tinggi, dan ketergantungan yang relatif rendah). Kuadran II (kanan atas) merupakan wilayah variabel kontrol. Kuadran III (kanan bawah) merupakan wilayah variabel keluaran, yang bersifat sangat tergantung dan hanya sedikit pengaruh. Kuadran IV (kiri bawah) merupakan wilayah variabel marjinal, kelompok ini akan dikeluarkan dari analisis. Variabel yang berada pada kuadran I dan II merupakan variabel kuat, dan akan dipilih sebagai variabel penentu dalam analisis selanjutnya.

Berdasarkan grafik diatas, maka pengelompokan variabel-variabel yang telah diidentifikasi pada tahap awal analisis, adalah sebagai berikut:

(a). Kelompok variabel penggerak (driver) adalah variabel 8 (transparansi); variabel 12 (posisi tawar masyarakat); dan variabel 3 (kejelasan penguasaan dan pemilikan lahan).

(b). Kelompok variabel kontrol adalah: variabel 9 (komunikasi); variabel 1 (nilai lahan); variabel 11 (kelembagaan dan keorganisasian); variabel 2 (nilai ekonomi lokasi); dan variabel 14 (potensi konflik).

(c). Kelompok variabel keluaran adalah: variabel 4 (kualitas kawasan); variabel 7 (Kompensasi); dan variabel 6 (insentif).

(d). Kelompok variabel marjinal adalah: variabel 10 (pengalaman masa lalu); variabel 13 (konsistensi dalam proses penataan); dan variabel 5 (ketersambungan antara perencanaan dengan kebutuhan/keinginan masyarakat).

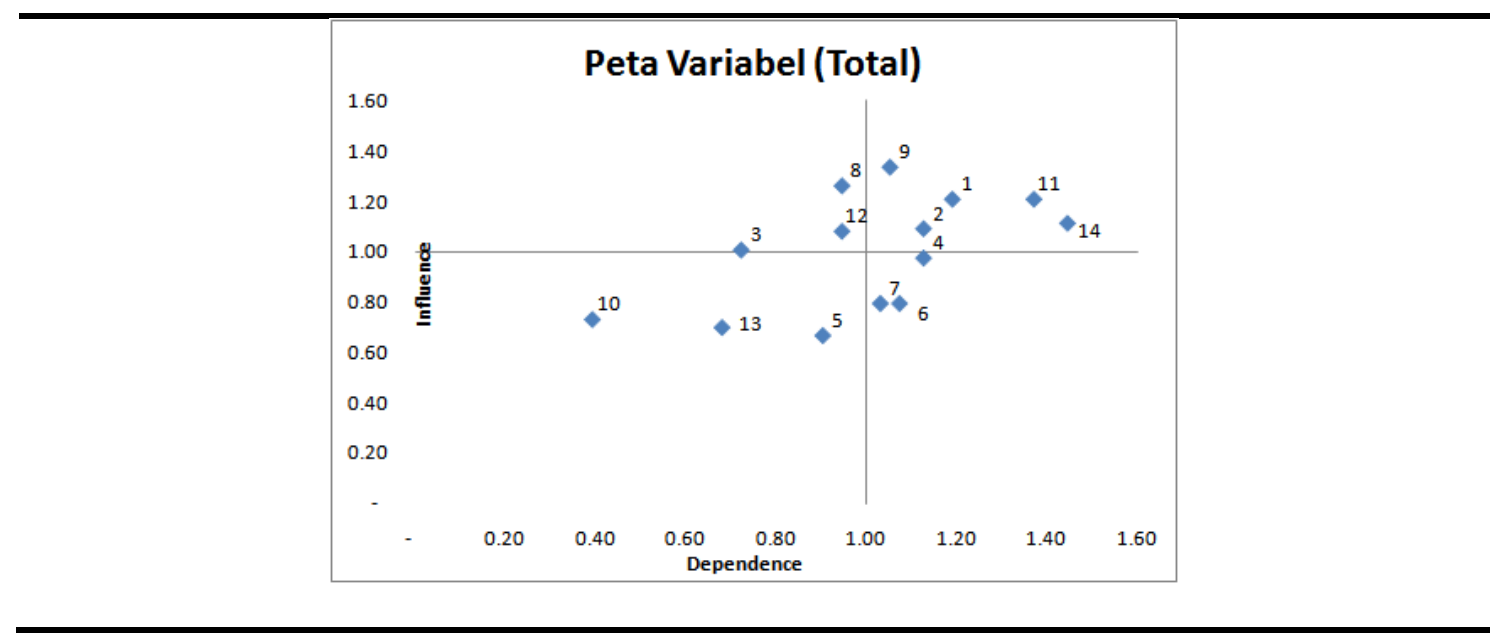

\section{Gambar 6 Peta Kekuatan Variabel}

\section{Identifikasi Kondisi Variabel dan Perumusan Skenario ke Depan}

Setelah mengidentifikasi variabel-variabel terpilih, berikutnya adalah merumuskan atau mendefinisikan kondisi variabel-variabel tersebut di masa depan (atau disebut juga sebagai analisis morfologi) yang bertujuan untuk menjajaki domain masa depan yang mungkin terjadi, serta mengemukakan alternatif-alternatif yang relevan.

Berdasarkan tabel kemungkinan kondisi variabel-variabel terpilih, selanjutnya dilakukan pengembangan skenario-skenario berdasarkan susunan kemungkinan kondisi setiap variabel tersebut. Skenario-skenario tersebut dapat dikembangkan dengan mengambil sebagian dari kombinasi kondisi variabel-variabel diatas. Pengambilan sebagian kombinasi tersebut dilakukan dengan mempertimbangkan relevansi serta kemungkinan realisasinya di masa depan.Proses identifikasi menghasilkan beberapa skenario yang perlu dipertimbangkan dan/atau diantisipasi ke depan untuk memastikan kinerja sistem penataan 
kawasan ke depan. Beberapa skenario yang dipandang relevan untuk dipertimbangkan tersebut adalah sebagai berikut.

Tabel 8 Kemungkinan Kondisi Variabel Terpilih

\begin{tabular}{|c|c|c|c|c|c|}
\hline \multirow{2}{*}{ Variabel } & \multirow{2}{*}{ Kode } & \multicolumn{4}{|c|}{ Kondisi yang mungkin terjadi } \\
\hline & & 1 & 2 & 3 & 4 \\
\hline Transparansi & A & $\begin{array}{l}\text { Kurang } \\
\text { Transparan }\end{array}$ & $\begin{array}{l}\text { Transparan dalam } \\
\text { informasi, tapi } \\
\text { masih sulit di } \\
\text { klarifikasi }\end{array}$ & $\begin{array}{l}\text { Transparan } \\
\text { dalam } \\
\text { informasi, dan } \\
\text { tersedia akses } \\
\text { untuk proses } \\
\text { klarifikasi }\end{array}$ & $\begin{array}{l}\text { Transparan dalam } \\
\text { informasi, difasilitasi } \\
\text { wahana atau jalur } \\
\text { untuk klarifikasi }\end{array}$ \\
\hline $\begin{array}{l}\text { Posisi Tawar } \\
\text { Masyarakat }\end{array}$ & B & $\begin{array}{l}\text { Sebagai } \\
\text { Objek } \\
\text { penataan }\end{array}$ & $\begin{array}{l}\text { Posisi atau subyek } \\
\text { untuk memberikan } \\
\text { masukan dalam } \\
\text { proses penataan }\end{array}$ & $\begin{array}{l}\text { Posisi atau } \\
\text { subyek untuk } \\
\text { bernegosiasi } \\
\text { dalam proses } \\
\text { penataan }\end{array}$ & \\
\hline $\begin{array}{l}\text { Kejelasan } \\
\text { tenurial }\end{array}$ & C & $\begin{array}{l}\text { Semakin } \\
\text { tidak jelas }\end{array}$ & Tetap tidak jelas & Semakin jelas & \\
\hline Komunikasi & $\mathrm{D}$ & $\begin{array}{l}\text { Satu arah, } \\
\text { belum } \\
\text { memadai } \\
\text { untuk } \\
\text { feedback }\end{array}$ & $\begin{array}{l}\text { Dua arah, belum } \\
\text { cukup efektif dan } \\
\text { intensif }\end{array}$ & $\begin{array}{l}\text { Dua arah, } \\
\text { berjalan baik } \\
\text { (efektif) dan } \\
\text { Intensif }\end{array}$ & \\
\hline Nilai Lahan & E & & Tetap & Meningkat & \\
\hline $\begin{array}{l}\text { Kelembagaan } \\
\text { dan } \\
\text { Keorganisasi } \\
\text { an }\end{array}$ & $\mathrm{F}$ & $\begin{array}{l}\text { Kelembagaan } \\
\text { yang efektif } \\
\text { di tingkat } \\
\text { masyarakat }\end{array}$ & $\begin{array}{l}\text { Kelembagaan yang } \\
\text { efektif di tingkat } \\
\text { masyarakat dan } \\
\text { pelaku penataan }\end{array}$ & $\begin{array}{l}\text { Kelembagaan } \\
\text { yang efektif di } \\
\text { tingkat } \\
\text { masyarakat, } \\
\text { pelaku, dan } \\
\text { pemerintah }\end{array}$ & \\
\hline $\begin{array}{l}\text { Nilai } \\
\text { Ekonomi } \\
\text { Lokasi }\end{array}$ & G & $\begin{array}{l}\text { Kesempatan } \\
\text { tidak (belum) } \\
\text { banyak } \\
\text { terbuka }\end{array}$ & $\begin{array}{l}\text { Terbuka } \\
\text { kesempatan } \\
\text { peningkatan } \\
\text { ekonomi } \\
\text { masyarakat }\end{array}$ & $\begin{array}{l}\text { Adanya } \\
\text { dukungan } \\
\text { fasilitas yang } \\
\text { memadai bagi } \\
\text { peningkatan } \\
\text { ekonomi } \\
\text { masyarakat }\end{array}$ & \\
\hline $\begin{array}{l}\text { Potensi } \\
\text { Konflik }\end{array}$ & $\mathrm{H}$ & Berkurang & Tetap & Meningkat & \\
\hline
\end{tabular}

Tabel 9 Beberapa Skenario Beserta Deskripsinya

\begin{tabular}{crl}
\hline No & Skenario & \\
\hline 1 & Status Quo & A2: Transparan dalam informasi, tapi masih sulit di klarifikasi \\
& B1:Posisi tawar sebagai objek penataan \\
& C2:Sistem tenurial tetap tidak jelas \\
& D1:Komunikasi satu arah, dan belum ada akses untuk feedback \\
& E2: Nilai lahan tetap \\
& F1: Ada kelembagaan efektif di level masyarakat \\
& G1: Belum banyak kesempatan untuk meningkatkan ekonomi masyarakat \\
& dengan memanfaatkan lokasi \\
& H2: Potensi konflik tetap \\
& A1:Kurang transparan \\
& B1:Posisi tawar sebagai objek penataan \\
& C1:Sistem tenurial Semakin tidak jelas \\
& D1:Komunikasi satu arah, dan belum ada akses untuk feedback \\
& E2: Nilai Lahan Tetap \\
& F1: Ada kelembagaan efektif di level masyarakat \\
& G1: Belum banyak kesempatan untuk meningkatkan ekonomi masyarakat \\
& dengan memanfaatkan lokasi \\
\hline
\end{tabular}




\begin{tabular}{lll}
\hline No & Skenario & \\
\hline \multirow{3}{*}{ Positif } & H3: Potensi Konflik Meningkat \\
& A3:Transparan dalam informasi, dan tersedia akses untuk proses klarifikasi \\
& B2: Posisi tawar sebagai subyek yang mendapatkan akses untuk memberikan \\
& masukan dalam proses penataan \\
& C3:Sistem tenurial semakin jelas \\
& D2:Komunikasi Dua arah, namun belum cukup efektif dan intensif \\
& E2: Nilai lahan tetap \\
& F2: Kelembagaan yang efektif di tingkat masyarakat dan pelaku penataan \\
& G2: Terbuka kesempatan peningkatan ekonomi masyarakat dengan \\
& memanfaatkan lokasi \\
& H2: Potensi konflik tetap \\
& A4: Transparan dalam informasi, difasilitasi wahana atau jalur untuk klarifikasi \\
& B3: Posisi atau subyek untuk bernegosiasi dalam proses penataan \\
& C3: Sistem tenurial semakin jelas \\
& D3: Komunikasi Dua arah, berjalan baik (efektif) dan Intensif \\
& E2: Nilai lahan meningkat \\
& F3: Kelembagaan yang efektif di tingkat masyarakat, pelaku, dan pemerintah \\
& G3: Adanya dukungan fasilitas yang memadai bagi peningkatan ekonomi \\
& masyarakat dengan memanfaatkan lokasi \\
& H1: Potensi konflik berkurang \\
\hline
\end{tabular}

\section{Implikasi Strategis dan Aksi Antisipatif}

Tabel susunan beberapa skenario perilaku sistem sebagaimana diatas selanjutnya menjadi dasar bagi perumusan implikasi strategis dan aksi antisipatif. Implikasi strategis dan aksi antisipatif ini diformulasikan menurut masing-masing skenario sebagai berikut.

\section{Skenario Status-quo}

Skenario Status-quo ini menggambarkan belum terpenuhinya prakondisi yang dibutuhkan untuk dapat menjalankan penataan kawasan secara memadai. Proses transparansi (demikian juga komunikasi) yang masih bersifat satu arah. Posisi tawar masyarakat yang belum memadai untuk dapat berpartisipasi secara proporsional dan efektif dalam proses penataan. Kepemilikan dan penguasaan lahan/bangunan yang masih belum jelas. Kelembagaan masih terbatas dikalangan masyarakat saja, dan belum dapat menjembatani atau mengintegrasikan antar pelaku yang terkait dalam proses penataan. Nilai lahan belum ada peningkatan, walaupun secara lokasi cukup strategis. Sementara itu, kesempatan bagi masyarakat untuk meningkatkan ekonomi yang memanfaatkan keunggulan lokasi, belum banyak terbuka. Potensi konflik juga tidak/belum menunjukkan penurunan.

Dengan gambaran diatas, peningkatan kualitas kawasan sebagai sasaran dari proses penataan ini akan sulit untuk dicapai. Demikian juga persoalan kompensasi dan mekanisme insentif yang menjadi salah satu faktor yang dapat menjembatani kepentingan masyarakat, akan sulit untuk dapat diformulasikan secara adil/proporsional karena rendahnya tingkat partisipasi masyarakat, dan lemahnya transparansi serta komunikasi. Dengan pemilihan pendekatan Penyesuaian Ulang Lahan dalam proses penataan ini, harus diupayakan bagaimana mengangkat kondisi yang lebih suportif (mendukung) dari pada kondisi yang digambarkan dalam skenario ini.

Arah antisipasi atas kemungkinan munculnya skenario ini adalah bagaimana menghambat atau menutup jalur munculnya skenario ini. Gambaran skenario ini secara umum dekat dengan kondisi awal sebelum proses penataan, oleh karena itu proses penataan komunikasi yang efektif dengan masyarakat, serta pengembangan kelembagaan yang efektif juga perlu menjadi agenda pertama dan utama untuk menghindari skenario ini. Dalam proses komunikasi dan pengembangan kelembagaan tersebut, perlu juga disertai dengan 
memposisikan masyarakat secara lebih proporsional dalam konteks penataan kawasan tersebut. Ini sangat penting karena menjadi landasan bagi lahirnya partisipasi yang suportif pada proses penataan kawasan.

\section{Skenario Negatif}

Skenario Negatif ini menggambarkan belum terpenuhinya prakondisi yang dibutuhkan untuk dapat menjalankan penataan kawasan secara memadai. Gambaran umum kondisi ini dipandang lebih rendah dari skenario status-quo. Proses transparansi kurang memadai, demikian juga komunikasi yang masih bersifat satu arah. Posisi tawar masyarakat yang belum memadai untuk dapat berpartisipasi secara proporsional dan efektif dalam proses penataan. Kepemilikan dan penguasaan lahan/bangunan yang masih belum jelas. Nilai lahan belum ada peningkatan, walaupun secara lokasi cukup strategis. Kelembagaan masih terbatas dikalangan masyarakat saja, dan belum dapat menjembatani atau mengintegrasikan antar pelaku yang terkait dalam proses penataan. Sementara itu, kesempatan bagi masyarakat untuk meningkatkan ekonomi yang memanfaatkan keunggulan lokasi, belum banyak terbuka. Potensi konflik diperkirakan cenderung meningkat.

Dengan gambaran diatas, sebagaimana pada skenario status-quo, peningkatan kualitas kawasan sebagai sasaran dari proses penataan ini akan lebih sulit untuk dicapai. Persoalan kompensasi dan mekanisme insentif yang menjadi salah satu faktor yang dapat menjembatani kepentingan masyarakat, juga akan lebih sulit untuk dapat diformulasikan secara adil/proporsional karena rendahnya tingkat partisipasi masyarakat, dan lemahnya transparansi serta komunikasi. Dengan pemilihan pendekatan Penyesuaian Ulang Lahan dalam proses penataan ini, harus diupayakan bagaimana mengangkat kondisi yang lebih suportif (mendukung) dari pada kondisi yang digambarkan dalam skenario ini.

Sebagaimana pada skenario status-quo, arah antisipasi atas kemungkinan munculnya skenario ini adalah bagaimana menghambat atau menutup jalur munculnya skenario ini. Gambaran skenario ini secara umum dekat dengan kondisi awal sebelum proses penataan, bahkan cenderung lebih buruk akibat tingkat transparansi yang lebih rendah. Oleh karena itu proses penataan komunikasi yang efektif dengan masyarakat, serta pengembangan kelembagaan yang efektif juga perlu menjadi agenda pertama dan utama untuk menghindari skenario ini. Dalam proses komunikasi dan pengembangan kelembagaan tersebut, perlu juga disertai dengan memposisikan masyarakat secara lebih proporsional dalam konteks penataan kawasan tersebut. Ini sangat penting karena menjadi landasan bagi lahirnya partisipasi yang suportif pada proses penataan kawasan. Yang mendesak untuk ditingkatkan sebagai pembuka jalan bagi proses lainnya adalah peningkatan level transparansi, minimal informasi terkait rencana penataan dapat tersampaikan secara utuh kepada masyarakat.

\section{Skenario Positif}

Skenario Positif ini menggambarkan kondisi yang mengarah pada terpenuhinya prakondisi yang dibutuhkan untuk dapat menjalankan penataan kawasan secara memadai. Gambaran umum kondisi ini dipandang lebih baik dari kondisi awal sebelum proses penataan. Proses transparansi dalam informasi sudah memadai, dan tersedia akses untuk proses klarifikasi. Demikian juga komunikasi yang bersifat dua-arah, walaupun belum cukup efektif dan intensif. Posisi tawar masyarakat berada pada level mendapatkan akses untuk memberikan masukan dalam proses penataan. Kepemilikan dan penguasaan lahan/bangunan yang semakin jelas. Nilai lahan belum ada peningkatan, walaupun secara lokasi cukup strategis. Kelembagaan sudah berjalan efektif dalam menjembatani relasi kalangan masyarakat dan pelaku penataan. Kesempatan bagi masyarakat untuk 
meningkatkan ekonomi yang memanfaatkan keunggulan lokasi, sudah terbuka. Potensi konflik tetap, tidak menunjukkan peningkatan.

Dengan gambaran diatas, peningkatan kualitas kawasan sebagai sasaran dari proses penataan ini akan lebih memungkinkan untuk dicapai. Persoalan kompensasi dan mekanisme insentif yang menjadi salah satu faktor yang dapat menjembatani kepentingan masyarakat, juga akan lebih mudah untuk diformulasikan secara adil/proporsional karena didukung oleh tingkat partisipasi masyarakat, transparansi, dan komunikasi yang lebih baik. Dengan pemilihan pendekatan Penyesuaian Ulang Lahan dalam proses penataan ini, harus diupayakan bagaimana mencapai kondisi sebagaimana yang digambarkan dalam skenario ini. Bahkan, perlu didorong peningkatan pada beberapa kondisi yang masih belum optimal.

Arah antisipasi atas kemungkinan munculnya skenario ini adalah bagaimana menggerakkan atau mendorong kondisi menuju gambaran skenario positif ini. Selain itu, perlu juga ditutup atau diminimalkan peluang/ruang-ruang yang dapat menghambat, atau bahkan menggerakkan kondisi kearah yang sebaliknya. Gambaran skenario ini jelas sudah lebih baik dibandingkan dengan kondisi awal sebelum proses penataan. Pada saat kondisi skenario positif ini sudah tercapai, perlu dikelola secara baik untuk memastikan kondisi bergerak ke arah yang lebih baik, dan menutup celah untuk berbaliknya kondisi ke arah yang lebih buruk. Pengelolaan kondisi ini dilakukan dengan menjaga dan meningkatkan kualitas proses-proses transparansi, komunikasi, serta meningkatkan efektivitas kelembagaan yang menjembatani kepentingan masyarakat dan pelaku penataan.

\section{Skenario Progresif}

Skenario Progresif ini menggambarkan kondisi yang lebih kuat dalam memenuhi prakondisi yang dibutuhkan untuk dapat menjalankan penataan kawasan secara memadai. Gambaran umum kondisi ini dipandang lebih baik dari kondisi sebagaimana digambarkan dalam skenario positif. Proses transparansi sudah memadai, dan sudah difasilitasi wahana atau jalur untuk klarifikasi. Komunikasi berjalan dua-arah, efektif, dan intensif. Posisi tawar masyarakat berada pada level yang memungkinkan untuk melakukan negosiasi dalam proses penataan. Kepemilikan dan penguasaan lahan/bangunan yang semakin jelas. Nilai lahan menunjukkan ada peningkatan. Kelembagaan berjalan efektif dalam menjembatani relasi masyarakat, pelaku penataan, dan pemerintah. Tersedianya dukungan fasilitas yang memadai bagi masyarakat untuk meningkatkan ekonomi dengan memanfaatkan keunggulan lokasi. Suasana juga relatif lebih "sejuk" dengan potensi konflik yang cenderung berkurang.

Dengan gambaran diatas, peningkatan kualitas kawasan sebagai sasaran dari proses penataan ini akan lebih efektif untuk dicapai. Persoalan kompensasi dan mekanisme insentif yang menjadi salah satu faktor yang dapat menjembatani kepentingan masyarakat, jauh akan lebih mudah untuk diformulasikan secara adil/proporsional karena didukung oleh tingkat partisipasi masyarakat, transparansi, dan komunikasi yang lebih efektif. Dengan pemilihan pendekatan Penyesuaian Ulang Lahan dalam proses penataan ini, harus diupayakan bagaimana mencapai kondisi sebagaimana yang digambarkan dalam skenario ini, secara efektif.

Arah antisipasi atas kemungkinan munculnya skenario ini adalah bagaimana menggerakkan atau mendorong kondisi menuju gambaran skenario progresifini. Selain itu, perlu ditutup atau diminimalkan peluang/ruang-ruang yang dapat menghambat ke arah skenario ini, atau bahkan dapat menggerakkan kondisi kearah yang sebaliknya. Skenario ini merupakan gambaran skenario terbaik dibandingkan dengan kondisi awal sebelum proses penataan. Pada saat kondisi skenario progresif ini sudah tercapai, perlu dikelola secara baik untuk memastikan kondisi ini dapat berkelanjutan, serta menutup celah untuk berbaliknya kondisi ke arah yang lebih buruk. Pengelolaan kondisi ini dilakukan dengan menjaga dan 
meningkatkan kualitas proses-proses transparansi, komunikasi, serta efektivitas kelembagaan yang menjembatani kepentingan masyarakat dan pelaku penataan.

\section{KESIMPULAN}

Secara umum, preferensi masyarakat atas rencana penataan kawasan terbagi tiga, yaitu positif, ragu-ragu, dan negatif. Kelompok masyarakat yang bersikap ragu-ragu dan negatif umumnya dilandasi oleh ketidakadilan yang dirasakan dari pengalaman masa lalu terkait rencana penataan kawasan. Oleh karena itu, atas rencana penataan kawasan Kampung Braga yang ditawarkan, masyarakat sangat menekankan prinsip keadilan, yang mewujud dalam: (a) Mekanisme kompensasi yang memperhitungkan semua investasi (baik fisik maupun sosial) masyarakat selama ini; (b) Transparansi dalam perencanaan dan pelaksanaan penataan kawasan; (c) Tidak dijadikan korban perilaku rent seeking. Selain itu, mereka juga mengharapkan nilai ekonomi dan sosial, baik yang bersumber dari lokasi maupun hal-hal lain yang melekat pada kehidupan masyarakat penghuni selama ini dapat dipertahankan; serta kualitas lingkungan yang meningkat, salah satunya dalam bentuk ketersediaan sarana-sarana/fasilitas publik.

Gambaran preferensi masyarakat penghuni atas beberapa isu/aspek terkait dengan gagasan/rencana penataan kawasan Kampung Braga adalah sebagai berikut: (1) masyarakat sebenarnya mengakui atau melihat bahwa mereka hidup di lingkungan yang secara fisik tidak/kurang nyaman dan kurang sehat. Walaupun demikian, perasaan betah dan nyaman hadir di tengah masyarakat, yang dibentuk oleh kehidupan sosial yang guyub, dan berbagai kesempatan ekonomi yang dihadirkan oleh kawasan ini (faktor lokasi, dan lainnya); (2) masyarakat hidup di dalam hunian dengan status kepemilikan/penguasaan yang kompleks dan tidak jelas. Hubungan sewa menyewa antara masyarakat dengan pemilik lahan sudah berlangsung lama dan turun-temurun. Selain hunian, tanah yang menjadi alas bangunan hunian masyarakat juga dipecah-pecah menjadi beberapa bangunan yang disewakan. Ini berarti proses fragmentasi terjadi tidak hanya pada bangunan, tetapi pada tanah/lahannya. Kondisi ini melahirkan berbagai persoalan, terutama jika akan dilakukan pengalihan kepemilikan atau penguasaan; (3) pengalaman buruk yang pernah dialami, potensi resistensi dari masyarakat masih tetap ada, yang sebagiannya terlihat pada beberapa pertanyaan yang dikemukaan oleh masyarakat: (a) siapa yang bisa dijadikan pegangan; (b) bagaimana menghadapi pemilik uang/modal; (c) bagaimana masyarakat memiliki kekuatan daya tawar; (d) bagaimana melakukan negosiasi dengan pemerintah dan pihak-pihak lain; (e) apakah masyarakat mendapatkan bantuan advokasi; (5) dengan rencana penataan pada kawasan ini, masyarakat berharap akan menghasilkan kawasan hunian yang lebih sehat, rapi, ramah pada anak-anak, serta dapat memperluas kesempatan ekonomi. Selain itu, proses penataan harus berjalan secara adil.

Sementara itu, preferensi masyarakat juga dapat dipetakan dalam suatu analisis prospektif partisipatif yang memberikan identifikasi atau gambaran mengenai berbagai aspek atau variabel yang dianggap penting dalam menentukan proses penataan kawasan Kampung Braga ke depan. Variabel-variabel tersebut dikategorikan sebagai variabel penggerak dan variabel kontrol, sebagaimana berikut: (a) kelompok penggerak (driver) adalah: Transparansi, Posisi tawar masyarakat, dan Kejelasan penguasaan dan pemilikan lahan; (b) Kelompok kontrol adalah: Komunikasi, Nilai lahan, Kelembagaan dan keorganisasian, Nilai ekonomi lokasi, dan Potensi konflik. Berdasarkan variabel-variabel tersebut, dikembangkan gambaran kondisi ke depan yang disusun dalam skenario-skenario: (1) Skenario Status-quo; (2) Skenario negative; (3) Skenario positif; dan (4) Skenario progresif.

Skenario yang dianggap tidak mendukung adalah skenario status-quo dan skenario negatif. Kedua skenario ini tidak/kurang mendukung proses penataan kawasan Kampung Braga, khususnya dalam memperkuat capaian variabel-variabel kualitas kawasan, 
kompensasi, dan insentif. Arah antisipasi untuk kedua skenario ini adalah menutup atau menghambat jalan bagi terciptanya kondisi dalam kedua skenario tersebut, melalui penguatan transparansi, komunikasi, dan kelembagaan.

Skenario yang dianggap menguntungkan atau mendukung adalah skenario positif dan skenario progresif. Kedua skenario ini dapat mendukung proses penataan kawasan Kampung Braga, khususnya dalam memperkuat capaian variabel-variabel kualitas kawasan, kompensasi, dan insentif. Arah antisipasinya adalah adalah mendorong atau mempercepat pencapaian kondisi menurut kedua skenario, menjaga keberlanjutan dari kondisi tersebut, serta menutup atau menghambat jalan bagi bergeraknya kondisi ke arah sebaliknya. Hal ini diupayakan melalui pengelolaan transparansi, komunikasi, dan kinerja kelembagaan secara efektif.

\section{DAFTAR PUSTAKA}

Agrawal, P. 1999. Urban Land Consolidation: A Review of Policy and Procedures in Indonesia and other Asia Countries. GeoJournal, 49, 311-322.

Archer, R. W. 1994. Urban land consolidation for metropolitan Jakarta expansion, 1990-2010. Habitat International, 18(4), 37-52. http://doi.org/10.1016/0197-3975(94)90016-7

Bourgeois, R., F. Jesus. 2004. Participatory prospective analysis: Exploring and anticipating challenges with stakeholders. The United Nation: CAPSA Monograph No. 46.

Brown, K., E. Tompkins, W.N. Adger. 2001. Trade-off Analysis for Participatory Coastal Zone Decision-making. Norwich, NR4 7TJ, UK: Overseas Development Group, in collaboration with the Centre for Social and Economic Research on the Global Environment, Univ. of East Anglia.

Çete, M. 2010. Turkish Land Readjustment: Good Practice in Urban Development. Journal of Urban Planning and Development, 136(4), 373-380. http://doi.org/10.1061/(asce)up.1943-5444.0000031

Çete, Mehmet. 2010. Turkish Land Readjustment: Good Practice in Urban Development. Journal of Urban Planning and Development, 136(4). doi: 10.1061

Cornwall, A., R. Jewkes. 1995. What is participatory research? Soc. Sci. Med. 41 (12): 1667-1676.

Damai, Abdullah Aman. 2012. Sistem perencanaan tata ruang wilayah pesisir: studi kasus teluk Lampung [disertasi]. Bogor (ID): Institut Pertanian Bogor.

Fauzi, Akhmad. 2017 Juli. Analisis variabel keberlanjutan: Micmac. Draf buku analisis keberlanjutan. Siap terbit.

Firman, T. 2004. Major issues in Indonesia's urban land development. Land Use Policy, 21(4), 347-355. http://doi.org/10.1016/j.landusepol.2003.04.002

Home, R. 2007. Land readjustment as a method of development land assembly: A comparative overview. Town Planning Review,78(4), 459-483. http://doi.org/10.3828/tpr.78.4.4.65

Hong, Y.-H., \& Needham, B. (Eds.). (2007). Analyzing land readjustment: economics, law, and collective action. Cambridge, MA: Lincoln Institute of Land Policy.

Larsson, G. 1997. Land readjustment: A tool for urban development. Habitat International, 21(2), 141-152. http://doi.org/10.1016/s0197-3975(96)00059-8

Li, L.-H., \& Li, X. 2007 . Land Readjustment: An Innovative Urban Experiment in China. Urban Studies, 44(1), 81-98. http://doi.org/10.1080/00420980601023844

Liu, Y., Yang, R., \& Li, Y. 2013. Potential of land consolidation of hollowed villages under different urbanization scenarios in China.Journal of Geographical Sciences, 23(3), 503-512. http://doi.org/10.1007/s11442013-1024-8

Mitchell, D., Clarke, M., \& Baxter, J. (2008). Evaluating land administration projects in developing countries. Land Use Policy,25(4), 464-473. http://doi.org/10.1016/j.landusepol.2007.10.004

Mittal, J. 2014. Self-financing land and urban development via land readjustment and value capture. Habitat International, 44, 314-323. http://doi.org/10.1016/j.habitatint.2014.07.006

Mittal, J., \& Kashyap, A. (2015). Real estate market led land development strategies for regional economic corridors - A tale of two mega projects. Habitat International, 47, 205-217. http://doi.org/10.1016/j.habitatint.2015.01.026

Mukhija, V. 2002. An analytical framework for urban upgrading: property rights, property values and physical attributes. Habitat International, 26(4), 553-570. http://doi.org/10.1016/s0197-3975(02)00019-x 
Munoz-Gielen, D. 2012. Urban governance, property rights, land readjustment and public value capturing. European Urban and Regional Studies, 21(1), 60-78. http://doi.org/10.1177/0969776412440543

Sorensen, A. 1999. Land Readjustment, Urban Planning and Urban Sprawl in the Tokyo Metropolitan Area. Urban Studies, 36(13), 2333-2360. http://doi.org/10.1080/0042098992458

Sorensen, A. 2000. Conflict, consensus or consent: implications of Japanese land readjustment practice for developing countries. Habitat International, 24(1), 51-73. http://doi.org/10.1016/s01973975(99)00029-6

Sorensen, A. 2004. The Making of Urban Japan: Cities and Planning from Edo to the Twenty First Century (Nissan Institute Routledge Japanese Studies Series). London: Taylor \& Francis.

Supriatna, A., van der Molen, P., Andri, S., \& Paul, V. D. M. 2013. Land Readjustment As A Spatial Planning Tool For Kampung Upgrading (1st ed.). United States: LAP LAMBERT Academic Publishing.

Turk, S. S. 2005. Land readjustment: an examination of its application in Turkey. Cities, 22(1), $29-42$. http://doi.org/10.1016/j.cities.2004.10.004

Turk, S. S. 2007. An analysis on the efficient applicability of the land readjustment (LR) method in Turkey. Habitat International, 31(1), 53-64. http://doi.org/10.1016/j.habitatint.2006.04.001

Turk, S. S. 2008. An Examination for Efficient Applicability of the Land Readjustment Method at the International Context. Journal of Planning Literature, 22(3), 229-242. http://doi.org/10.1177/0885412207310283

Turk, S. S., \& Altes, W. K. K. 2011. Potential Application of Land Readjustment Method in Urban Renewal: Analysis for Turkey.Journal of Urban Planning and Development, 137(1), 7-19. http://doi.org/10.1061/(asce)up.1943-5444.0000035

Türk, Sevkiye Ş ence, \& Altes, Willem K Korthals. 2009. Applicability of Land Readjustment Method in Urban Renewal: An Examination of Three Cases in Turkey FIG Working Week 2009.

Türk, Sevkiye Ş ence. 2008. An Examination for Efficient Applicability of the Land Readjustment Method at the International Context. Journal of Planning Literature, 22(3), 229-242. doi: 10.1177/0885412207310283

Vitanen, K.. The Finnish Urban Land Readjustment Procedure in an International Context.

Wihadanto, Ake, Barus, Baba, Achsani, Noer Azam, Bratakusumah, Deddy S. 2017. Analisis karekteristik dan penilaian tingkat kekumuhan permukiman Kampung Braga Bandung. Jurnal Perencanaan Pembangunan Wilayah dan Perdesaan Volume 2 Nomor 2 2017. siap terbit.

William. 1983. Land readjustment: a different approach to financing urbanization. (W. A. Doebele, Ed.). United States: Lexington Books.

Yau, Y. 2009. A study on the acceptability of land readjustment for urban regeneration in Hong Kong. Urbani Izziv, 20(2), 105-114. http://doi.org/10.5379/urbani-izziv-en-2009-20-02-004

Yilmaz, A., Çă̆ daş , V., \& Demir, H. 2015. An evaluation framework for land readjustment practices. Land Use Policy, 44, 153-168. http://doi.org/10.1016/j.landusepol.2014.12.004 